\title{
Performance of reproductive system of Dichelops melacanthus (Hemiptera: Pentatomidae) subjected to buprofezin and pyriproxyfen: morphological analysis of ovarioles and testes
}

\author{
Desempenho do sistema reprodutivo de Dichelops melacanthus \\ (Hemiptera: Pentatomidae) submetidos à buprofezina e \\ piriproxifem: análise morfológica de ovaríolos e testículos
}

\author{
Paulo Sérgio Gimenez Cremonez ${ }^{*}$; Daniela de Oliveira Pinheiro ${ }^{2}$; Ângela Maria \\ Ferreira Falleiros ${ }^{2}$; Pedro Manuel Oliveira Janeiro Neves ${ }^{3}$
}

\begin{abstract}
The use of insecticides known as insect growth regulators, which are considered more selective to natural enemies, may be an alternative to integrated pest management of stink bugs of the main crops in Brazil. The objective of this study was to evaluate histological changes in the reproductive system of Dichelops melacanthus as well as female fecundity and egg fertility after use of growth-regulating insecticides. The insecticides used were buprofezin (a chitin biosynthesis inhibitor) at a sublethal concentration $\left(\mathrm{LC}_{30}\right.$ of $\left.2.99 \mathrm{~g} \mathrm{~L}^{-1}\right)$ and pyriproxyfen (a juvenile hormone analog) at a sublethal concentration $\left(\mathrm{LC}_{30}\right.$ of $8.35 \mathrm{~mL} \mathrm{~L}^{-1}$ ). A completely randomized experimental design was used, with 10 repetitions and 10 insects per experimental unit. Two bioassays were performed: in the first bioassay, fecundity (eggs/ female) and fertility (nymph eclosion) of the insects that survived the insecticides were evaluated; in the second bioassay, morphological alterations of the ovarioles of adult females and of the testes of adult male insects that survived the insecticides were evaluated. Buprofezin and pyriproxyfen did not affect the adult sex ratio or female fecundity. Pyriproxyfen reduced the percentage of ecloded nymphs (71.6\%) compared with that of the control and buprofezin ( 96.4 and $90.6 \%$, respectively) treatments and had an ovicidal effect, with direct and indirect action on embryogenesis. Morphological changes were observed in both treatments with buprofezin and pyriproxyfen. The alterations observed in female and male reproductive systems may occur by the action of buprofezin and pyriproxyfen on the morphology of both ovarioles and testes.
\end{abstract}

Key words: Dose-response curve. Endocrine disruption. Green-belly stink bug. Insect growth regulators. Reproductive organ morphology.

\section{Resumo}

A utilização de inseticidas conhecidos como reguladores de crescimento dos insetos, considerados mais seletivos a inimigos naturais, pode ser uma alternativa no manejo integrado no que se refere ao controle de percevejos-pragas das principais culturas no Brasil. Os objetivos deste trabalho foram avaliar alterações histológicas causadas no aparelho reprodutor de Dichelops melacanthus e a fecundidade das fêmeas e fertilidade de ovos, após o uso de inseticidas reguladores de crescimento. Os inseticidas

\footnotetext{
Eng $^{\circ}$ Agro $^{\circ}$ M.e, Discente, Curso de Doutorado em Fitossanidade, Programa de Pós-Graduação em Agronomia, Universidade Estadual de Londrina, UEL, Londrina, PR, Brasil. E-mail: paulogimz@gmail.com

$2 \operatorname{Prof}^{\text {as }} \operatorname{Dr}^{\text {as }}$, Departamento de Histologia, UEL, Londrina, PR, Brasil. E-mail: daniela_pinheiro@uel.br; angefal@uel.br

3 Prof. Dr., Departamento de Agronomia, UEL, Londrina, PR, Brasil. E-mail: pedroneves@uel.br

* Author for correspondence
} 
utilizados foram buprofezina (inibidor da biossíntese de quitina), na concentração subletal $\mathrm{CL}_{30} 2,99$ $\mathrm{g} \mathrm{L}^{-1}$, e o piriproxifem (análogo do hormônio juvenil) na concentração subletal $\mathrm{CL}_{30} 8,35 \mathrm{~mL} \mathrm{~L}^{-1}$. O delineamento experimental foi inteiramente casualizado, com 10 repetições e 10 insetos por repetição. Foram realizados dois bioensaios: no primeiro foi avaliada a fecundidade (número de ovos/fêmea) e a fertilidade (número de ninfas eclodidas) dos insetos que sobreviveram aos produtos. No segundo bioensaio, foram avaliadas as alterações morfológicas de ovaríolos de fêmeas e testículo de machos de percevejos adultos, que sobreviveram à ação dos inseticidas. Buprofezina e piriproxifem não afetaram a razão sexual de adultos ou mesmo a fecundidade das fêmeas. Piriproxifem reduziu a porcentagem de ninfas eclodidas $(71,6 \%)$ em relação à testemunha e buprofezina $(96,4$ e $90,6 \%$, respectivamente), tendo ação ovicida, direta ou indireta na embriogênese. Alterações morfológicas no testículo e ovaríolos foram evidenciadas em ambos os tratamentos com buprofezina e piriproxifem. As alterações observadas no sistema reprodutor feminino e masculino indicam ação de buprofezina e piriproxifem na morfologia de ovaríolo e testículos.

Palavras-chave: Curva dose-resposta. Desregulação endócrina. Percevejo-barriga-verde. Inseticidas reguladores de crescimento. Morfologia de órgãos reprodutores.

\section{Introduction}

The green-belly stink bug (Dichelops melacanthus Dallas) (Hemiptera: Pentatomidae) is an important pest of maize and wheat crops in Brazil (MANFREDI-COIMBRA et al., 2005) and occasionally occurs in the cultivation of soybean (DEPIERI; PANIZZI, 2011). This is an insect of the Neotropics that has emerged dramatically in the past two decades in southern Brazil as a result of the adoption of no-tillage systems, as the insect uses the leftover straw as a shelter (CHOCOROSQUI; PANIZZI, 2002, 2004).

Regarding agricultural pests and crop protection of stink bugs, studies based on the reproductive system can be of great importance. These studies can determine the status of individuals and populations in an agro-ecosystems (ESQUIVEL, 2011).

In insects, reproduction depends on the action of hormones, such as juvenile hormone ( $\mathrm{JH})$ and ecdysone (ZERA et al., 1998; SEIDELMANN et al., 2016). It is known that $\mathrm{JH}$ acts in lipid synthesis (ZIBAEE et al., 2011), which is important for formation of adult females, mainly for the production of vitellogenin (GUO et al., 2014; SMYKAL et al., 2014). Ecdysone is an important agent for the ecdysis of insects; in addition to controlling the biosynthesis of chitin, diapause and the immune system (LENAERTS et al., 2016), this hormone is also involved in the development of ovarian structure (ZERA; BOTTSFORD, 2001).

The use of insecticides with different modes of action instead of those commonly used in the control of stink bugs can be advantageous for resistance management and can be an alternative to integrated pest management, as in the case for insect growth regulators (IGRs) (SUN et al., 2015). This strategy involves focusing on selectivity for natural enemies and on beneficial insects.

IGRs were developed with the goal of disrupting the normal development of juveniles of arthropods (WILLIAMS, 1967; THOMAS; BHATNAGARTHOMAS, 1968; PENER; DHADIALLA, 2012), and IGRs are traditionally used in the control of lepidopteran larvae. However, IGRs can cause high percentages of mortality of stink bug nymphs (PRABHAKER; TOSCANO, 2007; FURIATTI et al., 2009; XU et al., 2011; CHOUDHARI; SINGH, 2015).

Studies in whitefly (Trialeurodes vaporariorum Westwood) (Hemiptera: Aleyrodidae) showed that the hatching rate of nymphs (HEIDARI et al., 2004) and female fertility (HEIDARI et al., 2005) were significantly reduced due to contact with two IGRs: the chitin biosynthesis inhibitor buprofezin and the $\mathrm{JH}$ analog pyriproxyfen. Xu et al. (2011) showed that pyriproxyfen and buprofezin affect the hatching of nymphs in the eggs of Bemisia tabaci Gennadius (Hemiptera: Aleyrodidae). 
Reports of products that inhibit chitin biosynthesis and that are involved in the losses of reproductive potential and development of insect ovaries and testes exist (CHANGMANN et al., 2008; GHAZAWY, 2012).

In cotton crops of central India, pyriproxyfen was more effective than acetamiprid and diafenthiuron at controlling leafhoppers (Hemiptera: Cicadellidae), white flies (Hemiptera: Aleyrodidae), aphids (Hemiptera: Coccidae) and thrips (Thysanoptera) (CHOUDHARI; SINGH, 2015).

Under laboratory conditions, Mojaver and Bandani (2010) observed that pyriproxyfen is harmful to nymphs and affects the sex ratio, weight and morphology of Eurygaster integriceps Puton adults (Hemiptera: Scutelleridae).

Therefore, the objectives of this work were to evaluate the effects of two IGRs, buprofezin and pyriproxyfen, on the reproductive performance as well as on testis and ovariole morphology of $D$. melacanthus.

\section{Materials and Methods}

Adults of D. melacanthus were obtained from the Instituto Agronômico do Paraná (IAPAR) and taken to the Laboratory of Pathology and Microbial Control of Insects of the Universidade Estadual de Londrina (UEL), where they were maintained in an acclimatized chamber $\left(25 \pm 1{ }^{\circ} \mathrm{C}\right.$ temperature; $65 \pm 5 \%$ relative humidity $[\mathrm{RH}] ; 14 \mathrm{~h}$ photoperiod) in clear polystyrene boxes $(11 \times 11 \mathrm{~cm})$ containing bean pods (Phaseolus vulgaris L.) (Fabaceae), peanuts (Arachis hypogaea L.) (Fabaceae) and soybeans (Glycine $\max$ L. Merrill) (Fabaceae) according to methodology described by FerreiraAgüero et al. (2014).

The applications of insecticides occurred on nymphs in the fourth instar stage (after approximately 23 days of development), and the concentrations were determined such that the nymphs could reach adulthood, necessitating a sublethal concentration $\left(\mathrm{LC}_{30}\right)$. For this, preliminary studies were conducted to determine the $\mathrm{LC}_{30}$, as this parameter is considered the basis for bioassays of sublethal concentrations (BAYRAM et al., 2010; SOHRABI et al., 2011).

Determination of $L_{30}$ of buprofezin and pyriproxyfen

Tests were conducted with six concentrations of each product: $0.8,1.6,3.2,4.8,6.4$ and $8.0 \mathrm{~g} \mathrm{~L}^{-1}$ of buprofezin (Applaud ${ }^{\text {TM }} 250 \mathrm{WP}$ ) and 2, 4, 8, 12, 16 and $20 \mathrm{~mL} \mathrm{~L}^{-1}$ of pyriproxyfen (Tiger ${ }^{\mathrm{TM}} 100$ $\mathrm{CE})$. Pure distilled water was used as the control treatment. The insecticides $(1.0 \mathrm{~mL}$ each $)$ were applied in Petri dishes with the aid of a micropipette and spread with a Drigalski spatula, after which the Petri dishes were placed in a flow chamber (30 min) for drying.

Afterward, 10 insects and a bean pod (for food) were placed in each dish; this setup was equivalent to one experimental unit. The treatments were repeated four times in a completely randomized design. The insects were kept in an acclimatized chamber $\left(25 \pm 1{ }^{\circ} \mathrm{C}\right.$ temperature; $65 \pm 5 \% \mathrm{RH}$; 14 $\mathrm{h}$ photoperiod) for 7 days until the evaluation of mortality.

Statistical regression analysis of the data was performed using $\mathrm{R}^{\circledR}$ software (R CORE TEAM, 2016) with the extension/package "drc" (FINNEY, 1971; RITZ; STREIBIG, 2005). After determining the $\mathrm{LC}_{30}$, the insecticides were diluted to concentrations with distilled water containing 200 ppm of polysorbate (Tween ${ }^{\mathrm{TM}} 20$ ) as a non-ionic surfactant according to the methodology of Sohrabi et al. (2011).

Bioassay I - Action on fecundity and fertility of Dichelops melacanthus

For this bioassay, fourth-instar nymphs of $D$. melacanthus (approximately 23 days of age) were 
randomly selected, and 100 of these nymphs were treated with buprofezin or pyriproxyfen at the concentrations described above. Nymphs in the control were treated with distilled water only.

Regarding applications, $1.0 \mathrm{~mL}$ ofeachinsecticide was applied to each Petri dish using a micropipette, spread with a Drigalski spatula and placed in a flow chamber (30 min) for drying. Afterward, 10 nymphs and a bean pod (as food) were placed in each dish; this setup constituted one experimental unit. The dishes were then placed in an acclimatized chamber $\left(25 \pm 1{ }^{\circ} \mathrm{C}\right.$ temperature; $65 \pm 5 \% \mathrm{RH}$; $14 \mathrm{~h}$ photoperiod). The insects were assessed on a daily basis to determine their cumulative mortality, and the insects that survived remained until they reached adulthood. The experimental design was completely randomized, with 10 repetitions. The data were subjected to analysis of variance, and the averages were compared by the Tukey test $(\mathrm{P} \leq 0.05)$.

Insects that had been in contact with each treatment and survived to adulthood were sexed by observing the distal plate on the back of the abdomen. The presence of a single plate indicated a male, whereas two lateral thorn shapes indicated a female (CORRÊA-FERREIRA; PANIZZI, 1999). Insects of opposite sex were formed into couples that were then placed into Petri dishes containing food and a cotton roll for egg laying with the purpose of enabling copulation and evaluating fecundity (eggs/ female) and fertility (nymphs hatched).

The insects remained in the acclimatized chamber $\left(25 \pm 1{ }^{\circ} \mathrm{C}\right.$ temperature; $65 \pm 5 \% \mathrm{RH}$; $14 \mathrm{~h}$ photoperiod) until the first copulation and oviposition for evaluation of fecundity. The copulated adults were subsequently subjected to the bioassay II protocol, as described below, for morphological analysis of the testes and ovarioles.

The egg masses were removed from the cotton rolls and placed into Petri dishes within clear polystyrene boxes with moistened filter paper as substrate; the boxes were maintained in the acclimatized chamber under the same conditions for fertility assessment.

Bioassay II - Histological evaluation of the reproductive system of Dichelops melacanthus subjected to buprofezin and pyriproxyfen

This bioassay was developed in the laboratory of the Department of Histology of UEL. After the first copulation, for collecting the testes and ovarioles, male and female D. melacanthus insects were anesthetized by cooling to $-4{ }^{\circ} \mathrm{C}$ and then dissected in Petri dishes with paraffin using a stereoscopic microscope. The insects were sexed, after which the reproductive system was removed and fixed immediately in Karnovsky solution (2.5\% glutaraldehyde $+4.0 \%$ paraformaldehyde in $0.1 \mathrm{M}$ phosphate buffer, $\mathrm{pH}$ 7.2) for $4 \mathrm{~h}$.

After fixation, the material was dehydrated in an increasing ethanol series (70\%, 90\% and 100\%), infiltrated in basic resin solution (Leica ${ }^{\circledR}$ Historesin) consisting of glycol methacrylate (GMA) $+100 \%$ ethanol (1:1) for $4 \mathrm{~h}$ at room temperature and then transferred to an infiltration solution (GMA resin + activator) for $24 \mathrm{~h}$ at room temperature. The material was subsequently added to activated resin (infiltration + hardener) and placed in an oven at 37 ${ }^{\circ} \mathrm{C}$ until complete drying and formation of block shapes.

The blocks were cut into $5-\mu \mathrm{m}$ pieces in a rotate microtome, and the slides were stained with Harris hematoxylin $(25 \mathrm{~min})$ and eosin $(20 \mathrm{~min})$ per the protocol of the Insect Laboratory of the Department of Histology modified by Cerri and Sasso-Cerri (2003). The slides were imaged using a light microscope (Zeiss ${ }^{\circledR}$ Axiophot) coupled with camera (Moticam ${ }^{\circledR} 2300$ 3.0 MP), and the images were analyzed and stored using the software program Motic ${ }^{\circledR}$ Plus Image 2.0. 


\section{Results and Discussion}

Determination of sublethal $L C_{30}$ concentrations of buprofezin and pyriproxyfen

The dose-response curve analysis concluded that sublethal concentrations for application in this experiment were as follows: buprofezin $\mathrm{LC}_{30}=2.99$ $\mathrm{g} \mathrm{L}^{-1}$ and pyriproxyfen $\mathrm{LC}_{30}=8.35 \mathrm{~mL} \mathrm{~L}^{-1}$.
Bioassay I - Fecundity and fertility of Dichelops melacanthus

The buprofezin and pyriproxyfen $\mathrm{LC}_{30}$ solutions were effective for the development of the bioassay, and the survival percentages were 72 and $66 \%$, respectively, until the sixth day of evaluation (144 $\mathrm{h}$ after application), at which time the surviving insects, being approximately 29 days old, were becoming adults (Table 1).

Table 1. Survival ( $\% \pm \mathrm{SE})$ of fourth-instar nymphs of Dichelops melacanthus subjected to sublethal concentrations $\left(\mathrm{LC}_{30}\right)$ of buprofezin or pyriproxyfen in the laboratory $\left(25 \pm 1{ }^{\circ} \mathrm{C}\right.$ temperature, $65 \pm 5 \% \mathrm{RH}, 14 \mathrm{~h}$ photoperiod) in Londrina, PR, 2016.

\begin{tabular}{|c|c|c|c|c|c|c|c|c|c|c|c|c|}
\hline \multirow{3}{*}{$\begin{array}{l}\text { Treatments } \\
\text { Control }\end{array}$} & \multirow{3}{*}{$\begin{array}{c}\mathrm{n} \\
100\end{array}$} & \multicolumn{11}{|c|}{ Survival $(\% \pm \mathrm{SE})$} \\
\hline & & \multicolumn{2}{|c|}{$24 \mathrm{HAA}$} & \multicolumn{2}{|c|}{48 HAA } & \multicolumn{2}{|c|}{72 HAA } & \multicolumn{2}{|c|}{96 HAA } & \multicolumn{2}{|c|}{$120 \mathrm{HAA}$} & $144 \mathrm{HAA}$ \\
\hline & & $100 \pm 0.0$ & $\mathrm{a}$ & $100 \pm 0.0$ & $\mathrm{a}$ & $100 \pm 0.0$ & $\mathrm{a}$ & $99 \pm 0.1$ & $\mathrm{a}$ & $93 \pm 0.2$ & $\mathrm{a}$ & $92 \pm 0.2 \quad a$ \\
\hline $\begin{array}{l}\text { Buprofezin } \\
\left(2.99 \mathrm{~g} \mathrm{~L}^{-1}\right)\end{array}$ & 100 & $98 \pm 0.1$ & $\mathrm{a}$ & $94 \pm 0.2$ & $\mathrm{a}$ & $85 \pm 0.3$ & $\mathrm{a}$ & $80 \pm 0.4$ & $\mathrm{ab}$ & $74 \pm 0.3$ & $\mathrm{~b}$ & $72 \pm 0.2 \quad b$ \\
\hline $\begin{array}{l}\text { Pyriproxyfen } \\
\left(8.35 \mathrm{~mL} \mathrm{~L}^{-1}\right)\end{array}$ & 100 & $100 \pm 0.0$ & $\mathrm{a}$ & $95 \pm 0.2$ & $\mathrm{a}$ & $88 \pm 0.2$ & $\mathrm{a}$ & $74 \pm 0.3$ & $\mathrm{~b}$ & $66 \pm 0.3$ & $\mathrm{~b}$ & $66 \pm 0.3 \quad b$ \\
\hline CV (\%) & - & 1.43 & & 4.96 & & 6.80 & & 10.23 & & 10.48 & & 10.05 \\
\hline
\end{tabular}

* Means followed by the same letter in a column do not differ significantly according to the Tukey test $(\mathrm{P} \leq 0.05)$; $\mathrm{SE}=\mathrm{Standard}$ error. HAA $=$ Hours after application. $\mathrm{n}=$ Initial number of nymphs. $\mathrm{CV}=$ Coefficient of variation.

The male:female sex ratio ranged from 1:0.84 (buprofezin) and 1:0.85 (control treatment) to 1:0.69 (pyriproxyfen). According to Del Vecchio and Grazia (1993), sex ratio values greater than 1:0.5 are considered normal in Hemiptera. The results from this bioassay demonstrate that the products do not significantly affect the sex ratio relative to that of the control treatment.

Couples formed after the bioassay in all treatments began to oviposit on the second day after isolation. Despite being higher, the average number of eggs/ female (fecundity) of the control treatment did not significantly differ from that of the buprofezin or pyriproxyfen treatment (Table 2). In a similar study, the IGRs buprofezin and diflubenzuron reduced the oviposition rate and hatching of nymphs of Diaphorina citri Kuwayama (Hemiptera: Psyllidae) as well as suppressed the rate of emergence of adults (TIWARI et al., 2012). In the present work, there was a significant difference in the percentage of hatched nymphs of $D$. melacanthus in the pyriproxyfen treatment $(71.6 \%)$ relative to hatched nymphs of the buprofezin and control treatments ( 90.6 and $96.4 \%$, respectively). Pyriproxyfen reduces lipid and protein synthesis (ZIBAEE et al., 2011), which are essential components for the formation of adult females; the product interferes with the growth and development of ovaries and affects oogenesis (GHASEMI et al., 2010; ZERA; BOTTSFORD, 2001). 
Table 2. Fecundity (eggs/female) and fertility (\% of nymphs ecloded) of Dichelops melacanthus after treatment of fourth-instar nymphs with sublethal concentrations $\left(\mathrm{LC}_{30}\right)$ of buprofezin or pyriproxyfen in the laboratory $\left(25 \pm 1{ }^{\circ} \mathrm{C}\right.$ temperature, $65 \pm 5 \% \mathrm{RH}, 14 \mathrm{~h}$ photoperiod) in Londrina, PR, 2016.

\begin{tabular}{cccc}
\hline Treatments & $\mathrm{n}$ & Eggs/female \pm SE & Nymphs ecloded (\%) \\
\hline Control & 42 & $11.26 \pm 0.66 \mathrm{a}$ & $96.4 \mathrm{a}$ \\
Buprofezin $\left(2.99 \mathrm{~g} \mathrm{~L}^{-1}\right)$ & 33 & $8.42 \pm 0.72 \mathrm{a}$ & $90.6 \mathrm{a}$ \\
Pyriproxyfen $\left(8.35 \mathrm{~mL} \mathrm{~L}^{-1}\right)$ & 27 & $7.19 \pm 0.79 \mathrm{a}$ & $71.6 \mathrm{~b}$ \\
\hline $\mathrm{CV}(\%)$ & - & 38.13 & 48.86 \\
\hline
\end{tabular}

*Means followed by the same letter in a column do not differ significantly according to the Tukey test $(\mathrm{P} \leq 0.05) ; \mathrm{n}=\mathrm{Number}$ of couples formed. $\mathrm{SE}=$ Standard error. $\mathrm{CV}=$ Coefficient of variation.

In studies with $B$. tabaci, embryos whose mothers were treated with pyriproxyfen or buprofezin did not develop, indicating that the products can be transferred from the reproductive system to oocytes in development (ISHAAYA; HOROWITZ, 1992; SOHRABI et al., 2011). Also, pregnant females of Aedes japonicus Theobald (Diptera: Culicidae) auto-disseminate the product for their larvae at concentrations effective enough to affect the emergence of the adult offspring originating from these larvae (TUTEN et al., 2016).

At the time of adult emergence of the stink bug, it was possible to observe symptoms of the buprofezin treatment, such as abdomen curving, feeding interruption, poor mobility and, in some cases, death. In Stomoxys calcitrans L. (Diptera: Muscidae), buprofezin significantly affected the development during immaturity and pupation at concentrations of $5 \mathrm{ppm}$, being most evident at larger dosages (LIU et al., 2012). Hemolymph extravasation was reported by Merzendorfer (2013) to be a symptom of chitin biosynthesis inhibitor agents.

In the present study, deleterious effects in the general morphology, such as kinks in the exuviae of ecdysis, bubbles in the cuticle and alterations of the mouthparts, of the adults of both the pyriproxyfen and buprofezin treatments were observed compared with those of the control. Studies with Nilaparvata lugens Stål (Hemiptera: Delphacidae) showed a deregulation pattern in the deposition of cuticle chitin caused by application of buprofezin (UCHIDA et al., 1985).

In addition to the symptoms described, various insects subjected to IGR treatments that had reached adulthood showed characteristics similar to those of juveniles, such as permanence of wing pads, rounded shape of the body and malformations of the external morphology of reproductive organs. Similar effects were observed in previous studies using pyriproxyfen and diflubenzuron on Nezara viridula L. (Hemiptera: Pentatomidae) (FERREIRA-AGÜERO et al., 2014).

In this study, both the buprofezin and pyriproxyfen products at sublethal concentrations $\left(\mathrm{LC}_{30}\right)$ caused deformations in external morphology, but these products did not affect the sex ratio or the fecundity of females. However, pyriproxyfen had an ovicidal effect, and this product may have direct or indirect action on embryogenesis, since the analysis indicated decreased hatching of nymphs.

Bioassay II - Histological modification of the reproductive system of Dichelops melacanthus subjected to buprofezin and pyriproxyfen

\section{Ovariole analyses}

The ovaries of $D$. melacanthus are telotrophic and meroistic, containing a trophic region (tropharium) with a germarium and nurse cells, vitellarium cells with oocytes (Figure 1A-1C), apical filaments and 
a pedicel; these anatomical features are found in insects of the same family, as described by other authors (CHAPMAN, 1998; KUGLER et al., 2006; OGORZAŁEK; TROCHIMCZUK, 2009; FORTES et al., 2011; GOMES et al., 2013). In the tropharium, in the ovariole distal region, oocytes and nurse cells are formed, which were also observed in D. melacanthus (Figure 1A-1C). Nurse cells are retained in the tropharium and have the function of garnishing the oocytes in formation. In the vitellarium, oocytes are formed, and they evolve with macromolecules and organelles that remain connected to nurse cells by cytoplasmic projections called trophic cords (Figure 1A, 1D, 1E).

Figure 1. Ovarioles of Dichelops melacanthus subjected to insect growth regulators. Hematoxylin and eosin staining process. A-C: Control treatment. A, B, G) See distribution of cytoplasmic vacuolation inside the oocyte. D-G: Buprofezin treatment. H, I: Pyriproxyfen treatment. Gr: germarium; NC: nurse cells; Tc: trophic cord; FC: follicular cells; Oo: oocyte; *: cytoplasmic vacuolation; Arrow: vitelinic membrane. Bar: $100 \mu \mathrm{m}$.
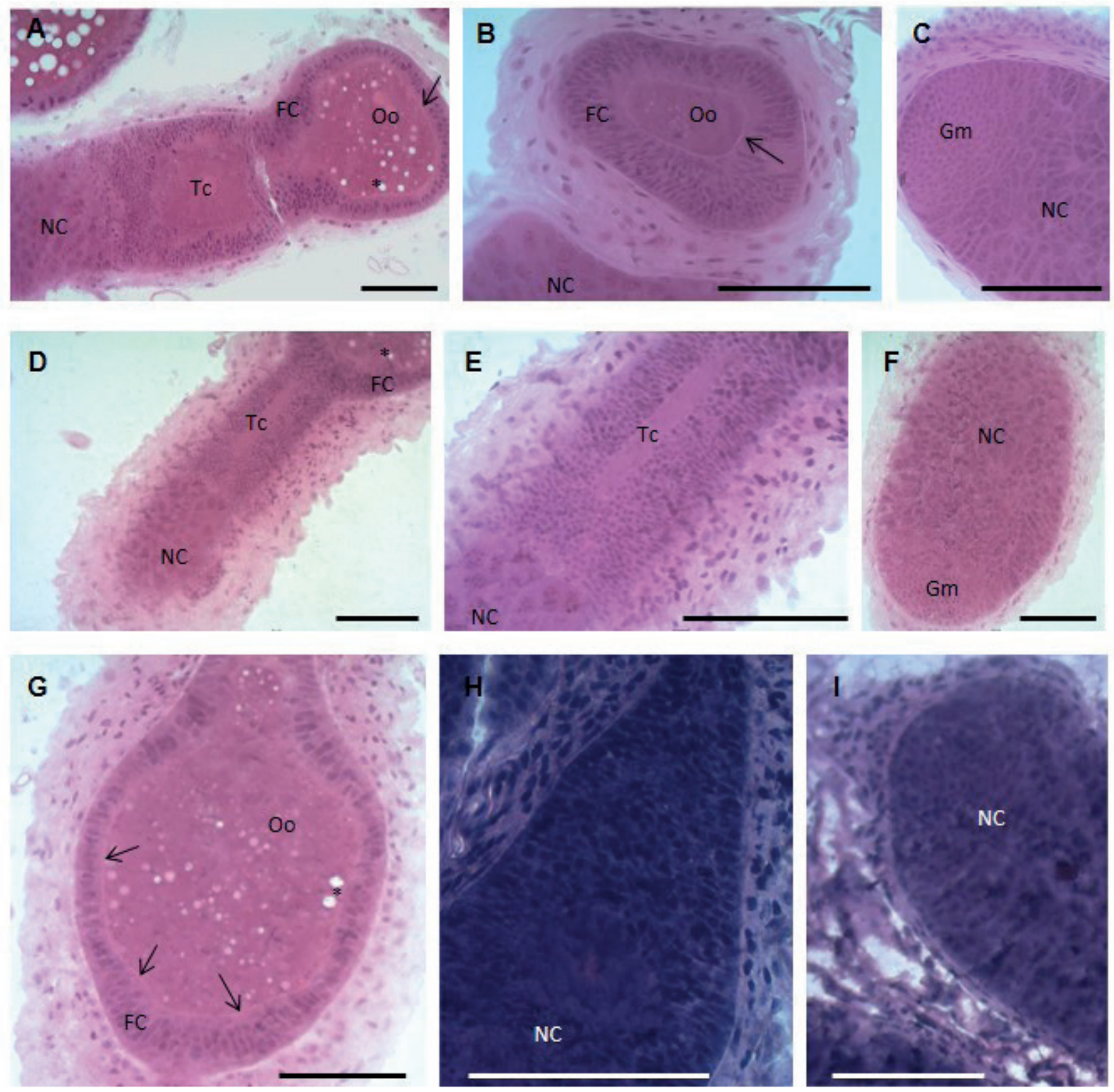

Semina: Ciências Agrárias, Londrina, v. 38, n. 4, suplemento 1, p. 2279-2292, 2017 
The oocytes observed during formation had a vitellin membrane in the surroundings and, more externally, a region of follicular cells that can be seen in Figures 1A, 1B and 1G. Within the oocyte, lipid droplets of various sizes were observed (Figure 1A, 1B, 1D, 1G). These observations were similar to those of Santos (2001), who examined the ovarioles of Diatraea saccharalis Fabr. (Lepidoptera: Crambidae) using transmission electron microscopy.

In insects of the control treatment, most images showed that the distribution of lipid droplets was possibly arranged around one of the poles of the oocyte (Figure 1A, 1B); however, after treatment with buprofezin, this pattern apparently changed to a non-preferential distribution throughout the oocyte (Figure 1G). Little is known about the distribution pattern of lipids within the oocyte; it is known only that there is an increase in the amount of lipid droplets depending on the stage of oocyte development (i.e., a more developed oocyte has a higher amount) (SANTOS, 2001). In studies with Schistocerca gregaria Forsskål (Orthoptera: Acrididae), the chitin biosynthesis inhibitor lufenuron affected the follicular layer organization and the arrangement of nutritive material in developing oocytes (GHAZAWY, 2012). Therefore, it is believed that the possible action of buprofezin may be related to a physiological change in the storage or even the synthesis and distribution of lipid material inside the oocyte. It was not possible to observe variation in lipid distribution in the insect material subjected to pyriproxyfen. However, this IGR does act on lipid synthesis in the hemolymph and fat bodies of E. integriceps (ZIBAEE et al., 2011) and of Plodia interpunctella Hübner (Lepidoptera: Pyralidae) (GHASEMI et al., 2010).

It was not possible to observe differences in nurse cells in the germarium using the buprofezin treatment compared to the control treatment. However, using pyriproxyfen, it was possible to observe destructuring of the nurse cells, resulting in a general gelatinous aspect of the cells, with no regularity or uniformity as observed for the insect cells of the control treatment (Figure 1H, 1I).

\section{Testis analyses}

In insects of the control treatment, the presence of five testicular follicles on each side of the abdomen of $D$. melacanthus was observed (Figure $2 \mathrm{~A}-2 \mathrm{C}$ ). Each testicle is covered externally by a support tissue called peritoneal sheath and separated internally by tunica propria (Figure 2A-2C). These anatomical and morphological characteristics of D. melacanthus share the same pattern as that of other insects of the same family (ÖZYURT et al., 2013). However, other authors characterizing morphological aspects in the testes of 18 species of Heteroptera reported variation in the number of testicular follicles (GOMES et al., 2013), but, regardless of the number of follicles, each portion of the testicular follicle contains a development zone (CHAPMAN, 1998).

It is known that during the process of spermatogenesis, which occurs from the apical to the basal region toward the vasa deferentia, the cells are arranged and divided into cysts (ROOSERUNGE, 1977). In this work, it was possible to observe in the distal region (in the area of growth) that the cysts of spermatogonia and spermatocytes were well evident (Figure 2A, 2E, 2I-K). The spermatogonia were rounded, small, numerous and well colored, with a rounded nucleus in the central portion and an evident nucleolus, whereas the larger cell volume had spermatocytes with a large nucleus occupying almost the whole cell (Figure 2A, 2E, 2I-K). In general, regardless of the type of animal, it is known that the spermatogonia are the first cells of the germ line and divide by mitosis, whereas the spermatocytes undergoing meiosis are for the development of spermatids (JUNQUEIRA; CARNEIRO, 2013). This process in insects occurs during maturation but then declines, as is evident in this study with $D$. melacanthus, where this process was observable following the sperm 
bundle formation (Figure 2B, 2D, 2F-H, 2L). This process was also observed in the D. melacanthus transformation zone, where the cysts of spermatids initiate the process of spermiogenesis, which involves a stretching process such that at the end (in the basal region) bundles of sperm are formed (Figure 2B, 2D, 2F-H, 2L), as described by other authors (CHAPMAN, 1998; PEREIRA; SANTOS, 2015). In addition, using transmission electron microscopy, these authors characterized two processes that give rise to eupyrene (nucleated) and apyrene spermatozoa (anucleate), which were not possible to observe in this study using only light microscopy.

Figure 2. Testes of Dichelops melacanthus subjected to insect growth regulators. Hematoxylin and eosin staining process. A-D: Control treatment. E-I: Buprofezin treatment. J-L: Pyriproxyfen treatment. 1-5: Numbered testicle follicles; E, J, K) See suggestive apoptotic bodies through the cysts. E-I) See disruption of internal and external sheaths. F-H, L) See disruption of sperm bundles. Gr: growth zone; M: maturation zone; T: transformation zone; Te: peritoneal sheath; Ti: tunica propria; Cc: cystic cells; Sg: spermatogonia; Sc: spermatocytes; St: spermatid; Sp: spermatozoid bundles, N: nucleolus; $\star$ : Cells in meiotic division; Arrow: suggestive image of apoptotic bodies. Bar: $100 \mu \mathrm{m}$.
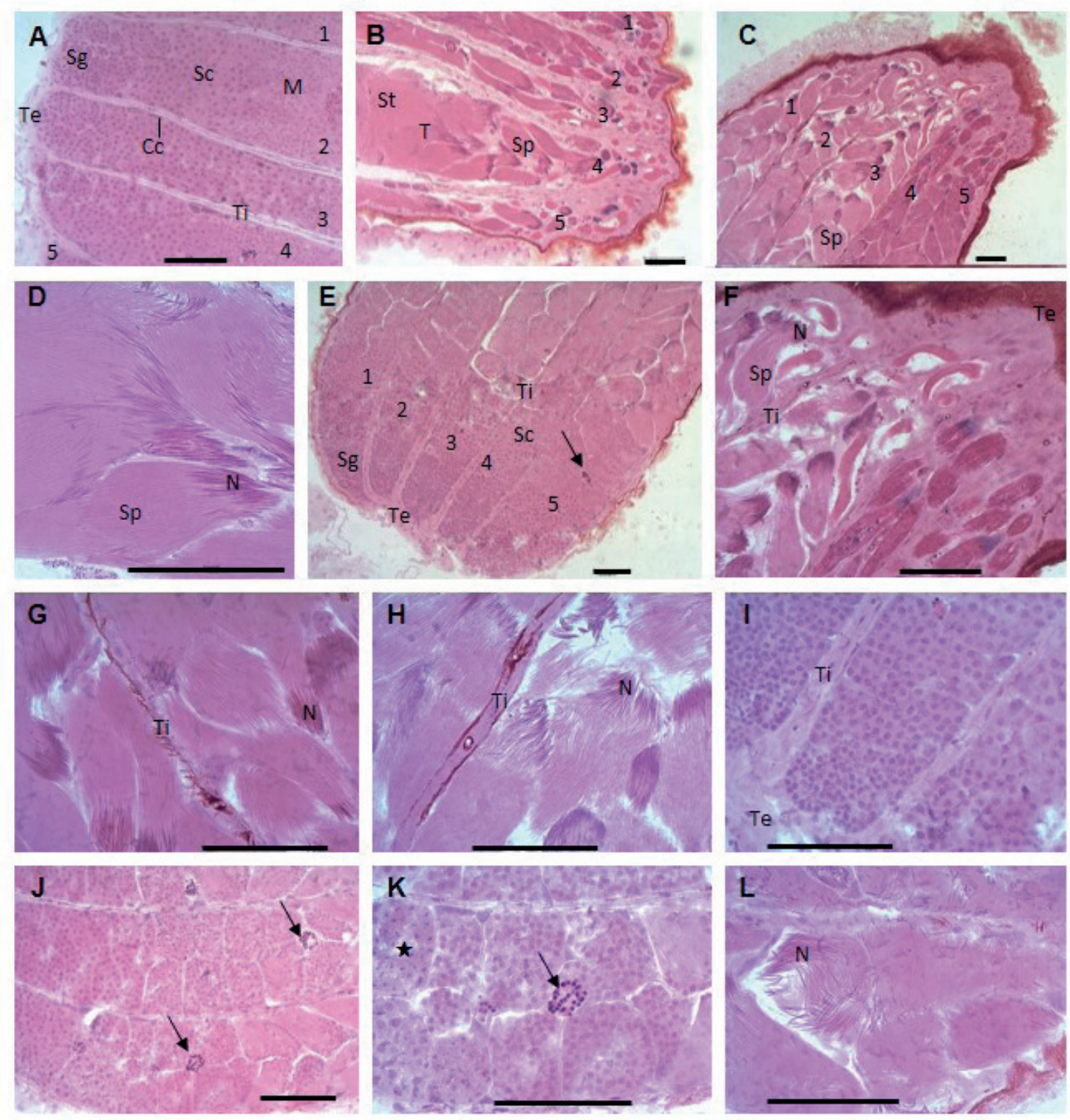
After treatment with buprofezin, no significant changes were observed in germ line cell morphology in D. melacanthus (Figure 2E-2I), but at the end of the process destructuring of the sperm bundles was observed. However, in the pyriproxyfen treatment the insects showed severe morphological alterations in the organization of their sperm bundles (Figure 2J-L). The bundles were disorganized, smaller and dispersed, suggesting that pyriproxyfen acts in the process of differentiation of spermatids in sperm (i.e., only in the process of spermiogenesis and not in the initial process of spermatogenesis).

Near the membrane of testicular follicles, it was possible to observe triangular-shaped accessory somatic cells with a large amount of cytoplasmic content (Figure 2A, 2I, 2K), described as cystic cells (PEREIRA; SANTOS, 2015), which did not show differences after treatment with any of the IGRs analyzed in this study.

In this study, after pyriproxyfen treatment, the presence of small rounded cells with a wellcolored nucleus was observed; these cells could be observed in groups or rows in the maturation and transformation zones (Figure 2E, 2J, 2K) in the case of infiltrated cells or even during the process of programmed cell death. According to Manaboon et al. (2012), JH has indirect action on programmed cell death in Omphisa fuscidentalis Hampson (Lepidoptera: Crambidae) by increasing the ecdysteroid hormone in the hemolymph of larvae in diapause, triggering the process. Although these cells are clearly visible, more specific studies need to be conducted to elucidate these findings, including immunohistochemical techniques and the determination of nuclear fragmentation by apoptosis using the terminal deoxynucleotidyl transferase dUTP nick end labeling (TUNEL) technique.

In the insects treated with buprofezin, there was more spacing between spermatogonium cysts and, consequently, spermatid cysts (Figure 2E-I) in addition to the dismantling of sperm bundles (Figure $2 \mathrm{~F}-\mathrm{H}$ ), which was also observed after the use of pyriproxyfen (Figure 2). Thus, the results of this study indicate that buprofezin and the pyriproxyfen are involved in dismantling germ cells and the connective tissue component of both external and internal sheaths. These results are similar to those of Ghazawy (2012), who also reported correlations between the action of the chitin biosynthesis inhibitor lufenuron and the ultrastructure and formation of testicular cysts of $S$. gregaria.

\section{Conclusions}

The IGRs buprofezin and pyriproxyfen applied at sublethal concentrations $\left(\mathrm{LC}_{30}\right)$ to fourth-instar nymphs of $D$. melacanthus did not affect the sex ratio of adults or the fecundity of females. Pyriproxyfen affected the hatchability of nymphs and had an ovicidal effect, acting directly or indirectly on embryogenesis.

The morphological changes observed in the female and male reproductive systems suggest that buprofezin is related to the physiological action of storage or the synthesis and distribution of lipid material inside the oocyte and that pyriproxyfen acts in the process of spermatid differentiation in sperm or in the process of spermiogenesis but not in the initial process of spermatogenesis. In addition to their action on germ line cells, it can also be concluded that buprofezin and pyriproxyfen may be related to the connective tissue disorganization of both peritoneal sheaths and of the tunica propria of the testicle.

\section{Acknowledgments}

The authors thank the staff of the Laboratory of Pathology and Microbial Control of Insects and the Department of Agronomy and Histology of the UEL for the development of this work, the Instituto Agronômico do Paraná (IAPAR) for the supply of insects and the Conselho Nacional de Desenvolvimento Científico e Tecnológico (CNPq) for financial support. 


\section{References}

BAYRAM, A.; SALERNO, G.; ONOFRI, A.; CONTI, E. Sub-lethal effects of two pyrethroids on biological parameters and behavioral responses to host cues in the egg parasitoid Telenomus busseolae. Biological Control, Orlando, v. 53, n. 2, p. 153-160, 2010.

CERRI, P. S.; SASSO-CERRI, E. Staining methods applied to glycol methacrylate embedded tissue sections. Micron, New York, v. 34, n. 8, p. 365-372, 2003.

CHANGMANN, Y.; YANG, J.; KANG, S.; KIM, G. Insecticidal properties of bistrifluron against sycamore lace bug, Corythuca ciliata (Hemiptera: Tingidae). Journal of Pesticide Science, Tokyo, v. 33, n. 1, p. 44-50, 2008.

CHAPMAN, R. F. The insects: structure and function. $4^{\text {th }}$ ed. Cambridge: Cambridge University Press, 1998. 770 p.

CHOCOROSQUI, V. R.; PANIZZI, A. R. Impact of cultivation systems on Dichelops melacanthus (Dallas) (Heteroptera: Pentatomidae) population and damage and its chemical control on wheat. Neotropical Entomology, Londrina, v. 33, n. 4, p. 487-492, 2004.

Influência da temperatura na biologia de ninfas de Dichelops melacanthus (Dallas, 1851) (Heteroptera: Pentatomidae). Semina: Ciências Agrárias, Londrina, v. 23, n. 2, p. 217-220, 2002.

CHOUDHARI, R. K.; SINGH, S. B. Evaluation of pyriproxyfen $10 \mathrm{EC}$ against sucking insect pests in cotton. Journal of Cotton Research and Development, Hisar, v. 29, n. 1, p. 99-102, 2015.

CORRÊA-FERREIRA, B. S.; PANIZZI, A. R. Percevejos da soja e seu manejo. Londrina: Embrapa-CNPSo, 1999. 46 p. (Circular técnica, 24).

DEL VECCHIO, M. C.; GRAZIA, J. Estudo dos imaturos de Oebalus ypsilongriseus (De Geer, 1773): III- Duração e mortalidade dos estágios de ovo e ninfa (Heteroptera: Pentatomidae). Anais da Sociedade Entomológica do Brasil, Londrina, v. 22, n. 1, p. 121-129, 1993.

DEPIERI, R. A.; PANIZZI, A. R. Duration of feeding and superficial and in-depth damage to soybean seed by selected species of stink bugs (Heteroptera: Pentatomidae). Neotropical Entomology, Londrina, v. 40, n. 2, p. 197-203, 2011.

ESQUIVEL, J. F. Estimating potential stylet penetration of southern green stink bug - a mathematical modeling approach. Entomologia Experimentalis et Applicata, Dordrecht, v. 140, n. 2, p. 163-170, 2011.
FERREIRA-AGÜERO, M. A.; NEVES, P. M. O. J.; CREMONEZ, P. S. G. Efeito do piriproxifem e diflubenzurom na reprodução de Nezara viridula (L.) (Hemiptera: Pentatomidae). Investigacion Agraria, San Lorenzo, v. 16, n. 2, p. 99-106, 2014.

FINNEY, D. J. Probit analysis. $3^{\text {th }}$ ed. Cambridge: Cambridge University Press, 1971. 333 p.

FORTES, P.; SALVADOR, G.; CÔNSOLI, F. L. Ovary development and maturation in Nezara viridula (L.) (Hemiptera: Pentatomidae). Neotropical Entomology, Londrina, v. 40, n. 1, p. 89-96, 2011.

FURIATTI, R. S.; PINTO JUNIOR, A. R.; WAGNER, F. O. Efeito do regulador de crescimento lufenurom em Nezara viridula (L., 1758). Revista Acadêmica: Ciências Agrárias e Ambientais, Curitiba, v. 7, n. 1, p. 73-78, 2009.

GHASEMI, A.; SENDI, J. J.; GHADAMYARI, M. Physiological and biochemical effect of pyriproxyfen on Indian meal moth Plodia interpunctella (Hübner) (Lepidoptera: Pyralidae). Journal of Plant Protection Research, Poznań, v. 50, n. 4, p. 416-422, 2010.

GHAZAWY, N. Ultrastructural observations on the gonads and neurosecretory cells of Schistocerca gregaria after treatment with lufenuron (CGA-184699). Journal of Orthoptera Research, Washington, v. 21, n. 12, p. 141148, 2012.

GOMES, M. O.; CASTANHOLE, M. M. U.; SOUZA, H. V.; MURAKAMI, A. S.; FIRMINO, T. S. S.; SARAN, P. S.; BANHO, C. A.; MONTEIRO, L. S.; SILVA, J. C. P.; ITOYAMA, M. M. Morphological aspects of the testes of 18 species of terrestrial Heteroptera from Northwestern São Paulo (Brazil). Biota Neotropica, São Paulo, v. 13, n. 3, p. 131-135, 2013.

GUO, W.; WU, Z.; SONG, J.; JIANG, F.; WANG, Z.; DENG, S.; WALKER, V.; ZHOU, S. Juvenile hormonereceptor complex acts on $\mathrm{Mcm} 4$ and $\mathrm{Mcm} 7$ to promote polyploidy and vitellogenesis in the migratory locust. PLoS Genetics, San Francisco, v. 10, n. 10, e1004702, 2014.

HEIDARI, A.; MOHARRAMIPOUR, S.; POORMIRZA, A. A.; TALEBI, A. A. Effects of buprofezin, pyriproxyfen and fenpropathrin on the growth population parameters of Trialeurodes vaporariorum Westwood (Hom.: Aleyrodidae). Iranian Journal of Agricultural Sciences, Karaj, v. 36, n. 2, p. 353-361, 2005.

Effects of buprofezin, pyriproxyfen and fenpropathrin on the reproductive parameters of Trialeurodes vaporariorum Westwood (Hom.: Aleyrodidae). Journal of Applied Entomology and Phytopathology, Tehran, v. 71, n. 2, p. 29-46, 2004. 
ISHAAYA, I.; HOROWITZ, A. R. Novel phenoxy juvenile hormone analog (pyriproxyfen) suppresses embryogenesis and adult emergence of the sweet potato whitefly (Homoptera: Aleyrodidae). Journal of Economic Entomology, Annapolis, v. 85, n. 6, p. 2113-2117, 1992.

JUNQUEIRA, L. C.; CARNEIRO, J. Histologia básica. 12. ed. Rio de Janeiro: Guanabara Koogan, 2013. 538 p.

KUGLER, J.; RUBSAM, R.; TRAUNER, J.; BUNING, J. The larval development of the telotrophic meroistic ovary in the bug Dysdercus intermedius (Heteroptera, Pyrrhocoridae). Arthropod Structure \& Development, Oxford, v. 35, n. 2, p. 99-110, 2006.

LENAERTS, C.; VAN WIELENDAELE, P.; PEETERS, P.; BROECK, J. V.; MARCHAL, E. Ecdysteroid signaling components in metamorphosis and development of the desert locust, Schistocerca gregaria. Insect Biochemistry and Molecular Biology, Oxford, v. 75, p. 10-23, 2016.

LIU, S. S.; LI, A. Y.; LOHMEYER, K. H.; PÉREZ DE LEÓN, A. A. Effects of pyriproxyfen and buprofezin on immature development and reproduction in the stable fly. Medical and Veterinary Entomology, Liverpool, v. 26, n. 4, p. 379-385, 2012.

MANABOON, M.; YASANGA, T.; SAKURAI, S.; SINGTRIPOP, T. Programmed cell death of larval tissues induced by juvenile hormone in the bamboo borer, Omphisa fuscidentalis. Journal of Insect Physiology, Oxford, v. 58, n. 9, p. 1202-1208, 2012.

MANFREDI-COIMBRA, S.; SILVA, J. J. da; CHOCOROSQUI, V. R.; PANIZZI, A. R. Danos do percevejo barriga-verde Dichelops melacanthus (Dallas) (Heteroptera: Pentatomidae) em trigo. Ciência Rural, Santa Maria, v. 35, n. 6, p. 1243-1247, 2005.

MERZENDORFER, H. Chitin synthesis inhibitors: old molecules and new developments. Insect Science, Malden, v. 20, n. 2, p. 121-138, 2013.

MOJAVER, M.; BANDANI, A. R. Effects of the insect growth regulator pyriproxyfen on immature stages of sunn pest, Eurygaster integriceps Puton (Heteroptera: Scutelleridae). Munis Entomology \& Zoology, Ankara, v. 5, n. 1, p. 187-197, 2010.

OGORZAŁEK, A.; TROCHIMCZUK, A. Ovary structure in a presocial insect, Elasmucha grisea (Heteroptera, Acanthosomatidae). Arthropod Structure \& Development, Oxford, v. 38, n. 6, p. 509-519, 2009.

ÖZYURT, N.; SELAMI, C.; SULUDERE, Z. The morphology and histology of the male reproductive system in Dolycoris baccarum Linnaeus 1758 (Heteroptera: Pentatomidae)-light and scanning electron microscope studies. Micron, New York, v. 44, p. 101106, 2013.
PENER, M. P.; DHADIALLA, T. S. An overview of insect growth disruptors: applied aspects. Advances in Insect Physiology, San Diego, v. 43, p. 1-162, 2012.

PEREIRA, M. C.; SANTOS, D. C. Testis morphology and dichotomic spermatogenesis in the sugarcane borer Diatraea saccharalis (F.) (Lepidoptera: Crambidae). Neotropical Entomology, Londrina, v. 44, n. 5, p. 481488, 2015.

PRABHAKER, N.; TOSCANO, N. C. Toxicity of the insect growth regulators, buprofezin and pyriproxyfen, to the glassy-winged sharpshooter, Homalodisca coagulate Say (Homoptera: Cicadellidae). Crop Protection, Guildford, v. 26, n. 4, p. 495-502, 2007.

R CORE TEAM. R: a language and environment for statistical computing. Vienna: R Foundation for Statistical Computing, 2016. Available at: <https://www.R-project. org/>. Accessed at: 25 apr. 2016.

RITZ, C.; STREIBIG, J. C. Bioassay analysis using R. Journal of Statistical Software, Los Angeles, v. 12, n. 5, p. 1-22, 2005.

ROOSE-RUNGE, E. C. The process of spermatogenesis in animals. Cambridge: Cambridge University Press, 1977. $214 \mathrm{p}$.

SANTOS, D. C. Vitelogênese e coriogênese em Diatraea saccharalis (Lepidoptera: Pyralidae): estudo morfológico e citoquímico. 2001. Tese (Doutorado em Zoologia) - Instituto de Biociências, Universidade Estadual Paulista Júlio de Mesquita Filho, Botucatu.

SEIDELMANN, K.; HELBING, C.; GÖBELER, N.; WEINERT, H. Sequential oogenesis is controlled by an oviduct factor in the locusts Locusta migratoria and Schistocerca gregaria: overcoming the doctrine that patency in follicle cells is induced by juvenile hormone. Journal of Insect Physiology, Oxford, v. 90, p. 1-7, 2016.

SMYKAL, V.; BAJGAR, A.; PROVAZNIK, J.; FEXOVA, S.; BURICOVA, M.; TAKAKI, K.; HODKOVA, M.; JINDRA, M.; DOLEZEL, D. Juvenile hormone signaling during reproduction and development of the linden bug, Pyrrhocoris apterus. Insect Biochemistry and Molecular Biology, Oxford, v. 45, p. 69-76, 2014.

SOHRABI, F.; SHISHEHBOR, P.; SABER, M.; MOSADDEGH, M. S. Lethal and sublethal effects of buprofezin and imidacloprid on Bemisia tabaci (Hemiptera: Aleyrodidae). Crop Protection, Guildford, v. 30, n. 9, p. 1190-1195, 2011.

SUN, R.; LIU, C.; ZHANG, H.; WANG, Q. Benzoylurea chitin synthesis inhibitors. Journal of Agricultural and Food Chemistry, Easton, v. 63, n. 31, p. 6847-6885, 2015. 
THOMAS, P. J.; BHATNAGAR-THOMAS, P. L. Use of juvenile hormone analogue as insecticide for pests of stored grains. Nature, London, v. 219, p. 949, 1968.

TIWARI, S.; CLAYSON, P. J.; KUHNS, E. H.; STELINSKI, L. L. Effects of buprofezin and diflubenzuron on various developmental stages of Asian citrus psyllid, Diaphorina citri. Pest Management Science, Sussex, v. 68, n. 10, p. 1405-1412, 2012.

TUTEN, H. C.; MOOSMANN, P.; MATHIS, A.; SCHAFFNER, F. Effects of pyriproxyfen on Aedes japonicus development and its auto-dissemination by gravid females in laboratory trials. Journal of the American Mosquito Control Association, Fresno, v. 32, n. 1, p. 55-58, 2016.

UCHIDA, M.; ASAI, T.; SUGIMOTO, T. Inhibition of cuticle deposition and chitin biosynthesis by a new insect growth regulator, buprofezin, in Nilaparvata lugens Stäl. Agricultural and Biological Chemistry, Tokyo, v. 49, n. 4, p. 1233-1334, 1985.

WILLIAMS, C. M. Third-generation pesticides. Scientific American, New York, v. 217, n. 1, p. 13-17, 1967.
XU, J. T.; SUN, D. W.; ZHAO, Q. C.; SHI, Q.; SHEN, J. L. Biological activities of buprofezin and pyriproxyfen on the eggs and nymphs of Bemisia tabaci. Acta Agriculturae Shanghai, Shanghai, v. 27, n. 2, p. 125-128, 2011.

ZERA, A. J.; BOTTSFORD, J. The endocrine-genetic basis of life-history variation: the relationship between the ecdysteroid titer and morph-specific reproduction in the wing-polymorphic cricket Gryllus firmus. Evolution, Lancaster, v. 55, n. 3, p. 538-549, 2001.

ZERA, A. J.; SANGER, T.; CISPER, G. L. Direct and correlated responses to selection on JHE activity in adult and juvenile Gryllus assimilis: implications for stagespecific evolution of insect endocrine traits. Heredity, London, v. 80, n. 3, p. 300-309, 1998.

ZIBAEE, A.; ZIBAEE, I.; SENDI, J. J. A juvenile hormone analog, pyriproxyfen, affects some biochemical components in the hemolymph and fat bodies of Eurygaster integriceps Puton (Hemiptera: Scutelleridae). Pesticide Biochemistry and Physiology, San Diego, v. 100, n. 3, p. 289-298, 2011. 
